\title{
How do chocolate lovers balance taste and ethical considerations?
}

\author{
Eline Poelmans and Sandra Rousseau
}

Faculty of Economics and Business, KU Leuven

To be published as: Poelmans, E. and S. Rousseau (forthcoming). How do chocolate lovers balance taste and ethical considerations? British Food Journal. Doi: 10.1108/BFJ-06-2015-0208

\section{Purpose}

The purpose of this paper is to investigate how chocolate lovers balance taste and ethical considerations when selecting chocolate products.

\section{Design/methodology/approach}

The dataset was collected through a survey at the 2014 "Salon du Chocolat" in Brussels, Belgium. We distributed 700 copies and received 456 complete responses (65\% response rate). Choice experiments were used to estimate the relative importance of different chocolate characteristics and to predict respondents' willingness to pay for marginal changes in those characteristics. We estimate both a conditional logit model and a latent class model to take possible preference heterogeneity into account.

\section{Findings}

On average, respondents were willing to pay 11 euro more for $250 \mathrm{~g}$ fairtrade labeled chocolate compared to conventional chocolate. However, taste clearly dominates ethical considerations. We could distinguish three consumer segments, each with a different tradeoff between taste and fairtrade. One group clearly valued fairtrade positively, a second group valued fairtrade to a lesser extent and a third group did not seem to value fairtrade.

\section{Originality/value}

Chocolate can be seen as a self-indulgent treat where taste is likely to dominate other characteristics. Therefore it is unsure to what extent ethical factors are included in consumer decisions. Interestingly the results indicate that a significant share of chocolate buyers still positively value fairtrade characteristics when selecting chocolate varieties.

Keywords: willingness to pay, fairtrade, choice experiment, chocolate consumption

Article classification: D12 Consumer Economics: Empirical Analysis; Q18 Agricultural Policy; Food Policy; Q5 Environmental Economics 


\section{Introduction}

One of the main ingredients of chocolate is cocoa. In response to persistent sustainability problems and consumers' increasing awareness for ethical chocolate products, the past years have seen a significant rise in certified cocoa production (SSI, 2014). Cited as one of the most promising business models for sustainable cocoa production (Fountain \& Hütz-Adams, 2012; Nieburg, 2014), certification is the procedure by which a certification body gives written assurance that the quality of the cocoa and the production process have been assessed and are conform to specified requirements (Fountain \& Hütz-Adams, 2010). While certified cocoa has existed since the late 1980s under organic certification schemes, it remained a niche product until the late 1990s, when reports by UNICEF and others revealed the widespread use of forced and child labour in African cocoa production (SSI, 2014). As a result, certification bodies increasingly became an integral part of the cocoa-chocolate supply chain (SSI, 2014). In 2010, the world cocoa production was estimated at almost 4.3 million tons, of which approximately 275000 tons $(6 \%)$ were certified (KPMG, 2012a).

Today, the cocoa-chocolate sector counts four internationally accepted certification bodies for cocoa production, namely Fairtrade Labelling Organizations International (FLO), UTZ certified, Rainforest Alliance and International Federation of Organic Agriculture Movements (IFOAM). In this paper we concentrate on the fairtrade labelling scheme as fairtrade represented the highest share of certified cocoa in 2010: 39\% was Fairtrade, 25\% UTZ certified, 20\% Rainforest Alliance and $15 \%$ had an organic label (KPMG, 2012a). Moreover, previous research on labeled chocolate in Flanders (Belgium) (Rousseau, 2015) showed that the Belgian consumers are more familiar with fairtrade $(60 \%$ of respondents were able to correctly identify the fairtrade label) than with other presented labels (such as the EU ecolabel (8\% of respondents) and the more recent EU organic label that was introduced in $2010(6 \%))$.

While desirable from a social point view, participating to a certification scheme leads to additional costs for chocolate producers. Besides certification fees paid by the producer, cocoa products will be more expensive since the Fairtrade foundation asks a premium from the buyers of fairtrade products. This premium is then invested in the local projects, such as clean drinking water, clinics or climate adaptation programs. ${ }^{1}$ Moreover, forced labor and child labor are prohibited, which can also lead to higher production costs (Fairtrade Foundation, 2011; 2014).

In order to evaluate the added value of certification, cocoa and chocolate producers need to understand consumer demand with regard to fairtrade chocolate products. Hence, it is interesting to study whether consumers are actually willing to buy fairtrade chocolate and whether they are willing to pay a price premium to cover for the additional producer costs. We use survey data to assess the impact of a fairtrade label on consumer decisions regarding chocolate consumption in

\footnotetext{
${ }^{1}$ For instance, the Fairtrade Foundation (2012, p. 1) mentioned that: "If a chocolate bar uses 500 tonnes of cocoa, then they must purchase 500 tonnes of cocoa on Fairtrade terms, including the payment of an additional \$200 Fairtrade premium per tonne."
} 
Belgium. Chocolate is a frequently bought product in Belgium with an average consumption of 7.3 $\mathrm{kg}$ per person in 2011, while the average was $5.04 \mathrm{~kg}$ per person EU-wide (CAOBISCO, 2013). Moreover, one in two Belgians claimed to have bought at least one fairtrade product in 2013 and the three most frequently bought products were coffee $(60 \%)$, fruit $(50 \%)$ and chocolate $(47 \%)$ (Trade for Development Centre, 2014). Still the average expense for fairtrade products only amounted to 8.6 euro per person in 2013 (Trade for Development Centre, 2014).

In the current study we concentrate on one segment of the market, namely consumers who like to buy and eat chocolate. This group of 'chocolate lovers' is likely to represent a large share of the demand in the chocolate market. Moreover, taste was shown to be a critical factor in previous studies looking at preferences for labeled products (e.g. De Pelsmacker et al., 2005; Andorfer \& Liebe, 2012) as well as those studying preferences for chocolate products (Tagbata \& Sirieix, 2008; Vlaeminck et al., 2015; Rousseau, 2015). Several studies have focused on the sensory and hedonic expectations of chocolate consumption (e.g. Januszewska \& Viaene, 2001; Torres-Moreno et al. 2012); while other studies concentrated on consumers perceptions and buying intention regarding chocolate products (e.g. Januszewska et al. 2000; Lybeck et al. 2006). Besides taste, consumers are increasingly interested in ethical attributes of food such as animal welfare, integration of handicapped people or fair prices for farmers (Zander \& Hamm, 2010). Therefore we investigate how chocolate lovers balance taste considerations with ethical considerations through a discrete choice experiment.

We use stated choice experiments to explicitly reflect the different attributes of chocolate products and to analyze the impact of each attribute separately. As Caswell (1998) and Yiridoe et al. (2005) noted, food products can be presented as a bundle of quality and safety attributes including the presence of a fairtrade label. A stated choice experiment allows us to explicitly disentangle the effects of separate product characteristics such as taste, labels and price. Since actual products on the markets often represent only limited sets of combinations of product characteristics (e.g. a fairtrade product will always be priced higher), actual sales data do not necessarily allow us to study the role of each separate characteristic on consumer choice.

Despite its benefits, the interpretation of results based on choice experiments has been questioned in the literature (e.g. List \& Gallet, 2001; Vossler et al., 2012) regarding the extent to which respondents may answer inconsistently when their choices do not have any real consequences. As an alternative to stated choice experiments, field or laboratory experiments with real products and actual cash transactions are used to increase the external validity of stated choices (Lusk \& Shogren, 2007; Norwood \& Lusk, 2011). While a hypothetical bias may be present, the validity of stated preference results has been confirmed (e.g., Vossler et al., 2012) and stated preference surveys are often the only practical approach to evaluate non-use values and preferences for nonmarket goods such as fairtrade. Moreover, due to the products' familiarity, the novelty bias when making choices in hypothetical markets should be minimal (List \& Shogren, 1999) and we can assume that consumers already have well-developed preferences for chocolate products. 
In the first section, we provide an overview of the worldwide supply and demand for fairtrade chocolate. In the second section, we investigate the existing research concerning the willingness to pay for fairtrade products. In the methods section, we describe the design of the choice experiments as well as our survey design. In the 'description of the dataset' section, we provide our sample characteristics, followed by the main effects of our choice experiment. We also discuss the results of a latent class model. The article ends with a concluding section.

\section{Worldwide supply and demand of fairtrade cocoa and chocolate}

Looking at the cocoa-chocolate value chain, we can distinguish several stages from the production and the industrial processing of cocoa beans to the actual chocolate production and the transportation and consumption of the end product chocolate.

In 2012, the world cocoa production was estimated at 4.6 million tons. Today, the largest part of the cocoa is produced in West Africa (68\%), East Asia (19\%) and South and Central America (14\%) (Poelmans \& Swinnen, 2016). Like most global agro-industrial commodity chains, the cocoachocolate supply chain is essentially buyer-driven, meaning that the farmers who grow and harvest the cocoa beans are price-takers on the global market (Fold, 2002). Close to $90 \%$ of world cocoa comes from small-scale, family-run farms (IDH, 2014; Barrientos, 2015). In 2010, 106.400 tons of fairtrade cocoa was produced, accounting for a share of $39 \%$ of all certified cocoa production and a share of $2.5 \%$ of total world cocoa production (KPMG, 2012a).

Although the cocoa production takes place in developing countries, the largest share of chocolate consumption takes place in industrialized countries. Yet, the last decade, the chocolate consumption volumes in the traditional markets - Western Europe and the US - are generally stagnating as these markets are becoming close to saturation (ICCO, 2012). Meanwhile, the emerging markets presented big growth prospects for confectioners. For instance, the BRIC-countries accounted for $55 \%$ of global confectionery retail in 2011 (KPMG, 2012b).

Besides shifting consumption patterns, cocoa smallholders face several sustainability challenges that weigh heavily on the sector's future. For instance, the productive base upstream the cocoachocolate value chain lacks economic sustainability. Due to weak producer-market linkages and limited access to financial and capacity development activities, smallholders have only little bargaining power on farm gate pricing mechanisms (Fountain \& Hütz-Adams, 2010). A significant environmental impact results from the use of fertilizers and pesticides during cocoa production. Moreover, cocoa production contributes to a substantial loss of biodiversity since the expansion of cocoa production has occurred at the expense of forestland i.e. a conversion of natural forest to agroforest as cacao beans are best planted into thinned forest, with shade, fertile soils, and a low weed pressure (Rice \& Greenberg, 2000, Myers at al. 2000; Clough et al., 2009). Lastly, a social issue is found in the fact that the productive base suffers from shortfalls in the social sustainability of cocoa cultivation (ICCO, 2007b). Cocoa farmers living in remote rural areas are denied access to 
basic infrastructure facilities and genuine educational opportunities which leads to widespread illiteracy (Oxfam, 2013).

Although these different issues can lead to stagnating cocoa yields and lower quality beans at farm level, the consequences are felt throughout the entire supply chain (Fountain \& Hütz-Adams, 2007). Whereas traders and cocoa grinders have difficulty in securing a supply of good quality cocoa, chocolate and confectionery companies are exposed to reputation risks as consumers increasingly demand socially and environmentally responsible products (ICCO, 2009). In fact, following a growing cocoa demand of 2 to $3 \%$ per year and stagnating cocoa yield figures, Fountain \& HützAdams (2012) fear a substantial shortfall between supply and demand by 2020. Faced with such supply-demand imbalances, the industry is pressed for strategies to increase production and has undergone a remarkable market transformation in the last decade, with the viability of cocoa farming now widely discussed on multi-stakeholder platforms (IDH, 2014).

Furthermore, chocolate consumption behavior across mature markets has been experiencing an increasing demand for premium chocolates such as: "organic, fairtrade, single-origin, reduced sugar and dark and high cocoa content" chocolates (ICCO, 2007a). "Additionally, the confectionery market is increasingly influenced by this changing consumer preferences for taste, convenience and health (ICCO, 2012). Thus, social responsibility, including attention for food origins, has had a significant impact on the chocolate industry (Redruello, 2012). One of the main categories to have benefited from this rise in social responsibility awareness are the fairtrade products, as this label's "primary purpose is to tackle poverty and empower producers in developing countries" (Fairtrade Foundation, 2011, p.10). For instance, worldwide fairtrade sales increased with 15\% between 2012 and 2013 (Fairtrade International, 2014).

While the market share of fairtrade-certified products is generally increasing and its growth has been very rapid over the past decade, it still comprises only a small share of the market. A possible explanation is that price, quality, convenience, and brand familiarity are still the most important decision criteria for many consumers (Carrigan and Attalla, 2001; Rousseau, 2015), while ethical factors are only considered by a minority of consumers. Thus for the near future, sustainable food markets are likely to remain niche markets (Vermeir \& Verbeke, 2006). Moreover, there are still limitations to the use of fairtrade certifications with regard to its economic and environmental impact, its empowerment impact and the quality of life of the farmers involved (Nelson \& Pound, 2009; Dragusanu et al., 2014). Examples show that for smallholder farmers non-income impacts of fairtrade are at least as important as income benefits; that fairtrade alone does not work and that it has to be complemented by other changes in coordination and development policies; that the individual producer knowledge of fairtrade is still very limited; that the premiums paid by consumers are not going directly to farmers, and that the success or failure of fairtrade can often be linked to certain types of products (Le Mare, 2008; Nelson \& Pound, 2009; Haight, 2011).

${ }^{2}$ For instance, Barry Callebaut - producing $40 \%$ of the world's industrial chocolate - states that its fairtrade certified chocolate sales grew by $400 \%$ from 2004 to 2008 (Pay, 2009). 


\section{Existing research on the fairtrade label and the willingness to pay for fairtrade products}

So far, several surveys have been conducted to find out whether consumers actually recognize the fairtrade label. A comprehensive survey of 2012 of more than 12.000 respondents across 24 countries showed that $57 \%$ of the respondents have seen the Fairtrade label on products and $64 \%$ say they trust the Fairtrade mark (Fairtrade International, 2012). The more familiar people are with Fairtrade, the more they trust it. For instance, in Belgium, 75\% of the respondents recognized the label and 79\% of these have trust in the label. Rousseau (2015), who investigated the potential of fairtrade and organic labels for chocolate in Belgium, found slightly lower figures for a sample of 600 Belgians: 60\% recognized the fairtrade label and 30\% considered the label to be a marketing tool.

Moreover, in recent years a large volume of studies have investigated the impact of fairtrade labels on consumer behavior. According to Jawtusch et al. (2012) the majority of the studies on fairtrade are on the socio-economic impact of these products. In our opinion we can divide the fairtrade studies into three separate groups. A first group has focused on describing the demographic characteristics of the ethical food consumer (e.g. Tallontire et al., 2001). Another group has concentrated on consumers' motivations for purchasing fairtrade food products (e.g. De Pelsmacker et al., 2005; Andorfer \& Liebe, 2012). A third group has focused on consumers' willingness to pay a price premium for fairtrade food products (e.g. De Pelsmacker et al., 2005; Loureiro \& Lotade, 2005; Basu \& Hicks, 2008). For instance, De Pelsmacker et al. (2005) have studied the WTP for fairtrade coffee in Flanders using conjoint analysis. They found that the brand was the most important characteristic of coffee, closely followed by flavor and the presence of a fairtrade label. Their results indicated that $10 \%$ of the sample wanted to pay a price premium of $27 \%$ (compared to a reference price of 1.87 euro per package of $250 \mathrm{~g}$ ). Overall, $50 \%$ of the consumers in their sample could be categorized as fairtrade lovers and likers.

Several food items have been the topic of this research into consumers' preferences for fairtrade food products, such as: yellow chili peppers (Garcia-Yi, 2015), pineapples (Poelman et al., 2008), coffee (Loureiro \& Lotade, 2005; Ruben \& Ford 2012) as well as chocolate (Tagbata \& Sirieix, 2008; Rousseau, 2015), and in a more general setting 'organic and fair trade' products and food products with 'sustainable attributes' (Annunziata et al., 2011; Annunziata \& Scarpato 2014). Overall, these studies show that a significant part of consumers state that they are willing to pay a price premium for fairtrade food products.

With regard to chocolate, previously, consumers' willingness to pay a price premium for organic and fairtrade dark chocolate compared to unlabeled dark chocolate has been measured using a lab experiment combined with tasting by Tagbata and Sirieix (2008). This study found that consumers are willing to pay an almost identical price for organic chocolate as for fairtrade chocolate (1.25 euro versus 1.31 euro), while consumers were willing to pay 0.7 euro for a standard chocolate bar on average. More recently, Rousseau (2015) performed a survey of consumers' decision making including a stated choice experiment concerning the purchase of chocolate in Flanders (Belgium) to 
test the conditions needed to have successful labelling schemes in practice. She considered three different kinds of chocolate: white, milk, and dark chocolate. Rousseau (2015) identified four distinct groups of consumers, each with different preferences regarding labels and chocolate. One group even had a negative WTP for organic chocolate. Overall, the conditions of having an effective labelling scheme are much better fulfilled for fairtrade labels than for organic labels in the Flemish chocolate market.

\section{Method}

In this section we describe the design of the choice experiments used to estimate the importance of different chocolate characteristics in consumers' purchasing decisions.

\subsection{Survey and questionnaire}

We presented the respondents with a three-part questionnaire. The first part dealt with sociodemographic questions. The second part involved questions relating to the preferences regarding chocolate consumption. The third part was a choice experiment which consisted of a series of choices between two chocolate products and the option not to buy any chocolate at all.

The survey was distributed on paper during the 'Salon du chocolat' in Brussels (Belgium), a one weekend event where both professionals and chocolate lovers can discover all kinds of chocolate products and chocolate usages. ${ }^{3}$ Thus our sample consists of consumers that frequently eat chocolate since we are particularly interested in studying whether these chocolate lovers care about fairtrade labels. The 2014 salon that took place in Belgium for the first time on 7-9 February 2014, counted some 30.000 visitors $^{4}$. Visitors were stimulated to participate in the survey by the opportunity of winning one out of twenty boxes of chocolates, each worth 25 euro. We distributed 700 copies and received 543 responses of which 456 were complete (65\% response rate).

\subsection{Choice experiments}

A discrete choice experiment (DCE) is a quantitative technique used for eliciting individual preferences. It is a stated preference technique that is especially suited to deal with multidimensional choices (Louviere \& Hensher, 1982; Louviere \& Woodworth, 1983). The DCE method describes a hypothetically marketed good in terms of its attributes and the levels that these attributes take (Hanley et al., 2001). Respondents are presented with alternative varieties of a good, differentiated by its attributes and levels, and asked to select their most preferred variety. A baseline alternative, corresponding to the opt-out situation, is included in each choice set so as to be able to interpret the results in standard welfare economic terms.

\footnotetext{
${ }^{3}$ The first 'Salon du Chocolat' took place in Paris in 1994. The subsequent salons - which took place in 29 cities on 4 different continents - were "helping to promote knowledge of and expertise in chocolate, from the bean to the bar, from producing countries to consumers" (Douce \& Jeantet, 2014).

${ }^{4}$ See http://brussels.salon-du-chocolat.com/
} 
The analysis of respondents' choices is based on random utility theory (Christie et al., 2004). Thus the overall utility generated by an individual's choice is assumed to depend on the utilities associated with its composing attributes and attribute levels. The utility $U_{i}$ derived by an individual of choosing alternative $i$ can be approximated by a linear utility function of the form (AmayaAmaya et al., 2008):

$$
U_{i}=A S C_{i}+X_{i}^{\prime} \beta+\varepsilon_{i}
$$

where $X_{i}$ represents an M-dimensional vector of attribute levels for alternative $i$, where $\beta$ is an Mdimensional vector of coefficients capturing generic marginal (dis)utilities of attributes and where $A S C_{i}$ captures the effect of unobserved factors for each of the alternatives. This model can be used to learn which attributes are most important for respondents' decisions and to predict respondents' willingness to pay (WTP) for marginal changes in attributes.

Our un-labelled DCE offered three options per choice card: hypothetical chocolate product A, hypothetical chocolate product B and the opt-out option. Regarding to the different attributes, we limited our choices to attributes that are both known by chocolate lovers and by consumers that only consume chocolate occasionally. Based on previous studies (Smith, 2004; Cidell \& Alberts, 2006; Tagbata \& Sirieix, 2008; ICCO, 2014; Rousseau, 2015) and pre-tests with students, we selected the following attributes to describe a chocolate product: the product type, the type of chocolate, the country of origin, the type of filling, the presence of a fairtrade label, the production process, and the price of the chocolate product. For each attribute we then selected the relevant levels which we now describe in more detail.

In our survey, the respondents could choose between three types of chocolate: a plain chocolate "tablet", "boxed chocolates" (pralines) and a "snack bar" (the collective name for all types of candy bars and small chocolate products). The respondents were given information and photographs of products to make sure they knew the difference between these three product types before taking part in the survey.

Regarding the chocolate type, the chosen attribute levels were "white", "milk" and "dark" chocolate. The types of filling selected were "no filling", "filled, but not with liquor" and "filled with liquor". There was a further division between "fairtrade" products and "no fairtrade" products 5 and between an "artisanal" and "industrial" production process.

We selected three different types of countries producing different qualities of chocolates. According to Cidell and Alberts (2006), the chocolate industry is an example of an industry where definitions of product quality are not connected to the countries where the raw materials (especially the cocoa bean) originate, but to the countries were the chocolate is manufactured. They argue that the history

\footnotetext{
${ }^{5}$ Since we used verbal descriptions of chocolate products, we wanted to be explicit about whether a product fulfilled the fairtrade requirements or not. We did not want to use the presence of absence of a label since consumers do not always trust these labels. So in this sense, our choice experiment did not perfectly mimic real product choices which might have introduced some bias in the responses.
} 
of chocolate making determined the trend to associate quality with the nationality (country) of the inventor. For instance, as Belgium was the first to start making "pralines", it is well-known for its (good quality) pralines (Cidell \& Alberts, 2006). The US and the UK were the first to introduce plain chocolate bars (e.g. Hershey's milk chocolate bar) and 'snack bars' (e.g. Mars) (Smith, 2004). Today, the US is still a well-known snack bars producer. China is one of the new chocolate countries and can - in our opinion - still be considered as an experimental nation when it comes to the production of good quality chocolate.

Further, six different price levels were used, ranging from cheap ( 2 euro for 1 tablet, 5 snack bars, or 1 box of 10 chocolates) to expensive (30 euro for 1 tablet, 5 snack bars, or 1 box of 10 chocolates). To choose the price levels, we looked at existing price ranges for these products in the Flemish supermarkets and confectionaries.

After selecting the different attribute levels we then determined, using Ngene, a D-efficient fractional factorial design with three blocks of six paired choice sets. Each respondent was randomly assigned to one of these three blocks. An example of such a choice set is presented in Table 1.

\begin{tabular}{|l|c|c|c|}
\hline Card 4B & O Option A & O Option B & O Neither \\
\hline Product type & Boxed chocolate & Chocolate snack bar & \\
\hline Chocolate type & White & Dark & \\
\hline Filling & Liquor filling & Liquor filling & \\
\hline Fair trade & Fair trade & No fair trade & \\
\hline Production process & Artisanal & Industrial & \\
\cline { 1 - 3 } Country of origin & China & Belgium & \\
\cline { 1 - 3 } Price (euro per 250 gr) & $\begin{array}{c}10 \text { euro for } 1 \text { box with } 10 \\
\text { chocolates }\end{array}$ & 6 euro for 5 bars & \\
\hline
\end{tabular}

Table 1: Example of a choice card

\subsection{Estimation method}

Data obtained from a choice experiment are often analyzed by conditional logit (CL) models. The CL model assumes a linear relationship between utility and attribute parameters, and requires the error term to be identically and independently distributed according to a Weibull distribution (Mariel et al., 2011). However, conditional logit models assume that preferences are homogeneous across respondents and only one fixed vector of parameters is estimated for the choice attributes (Hensher et al. 1999; Train, 2003). Conditional logit models can tackle heterogeneity by including socio-economic variables as interactions with attributes and alternative-specific constants, or by estimating different models for different subsets of data.

An alternative approach to incorporate heterogeneity consists of the latent class (LC) methods (McFadden, 1986; Boxall \& Adamowics, 2002). Latent class methods aim to distinguish consumer segments based on discrete observed measures. An LC model estimates consumers choices jointly 
with class membership based on the assumption that utility functions are different between classes, but identical within classes (Boxall \& Adamowics, 2002).

In our empirical analysis, besides estimating a standard conditional logit model, we also estimate a latent class model to address preference heterogeneity.

\section{Description of the dataset}

We now look at some descriptive characteristics of the respondents' sample (see table 2). A majority of the respondents was female $(69 \%)$ and all age categories were represented - with the majority (58\%) aged between 15 and 34 years old. Some $31 \%$ of respondents had a higher university education, $30 \%$ a secondary school education and $27 \%$ a higher non-university education. Moreover $46 \%$ of the respondents who revealed their income level had a net (post-tax) household income between 1500 and 3000 euro. Most respondents (75\%) had the Belgian nationality. Non-Belgian respondents were most likely to be French, Italian, Spanish or Dutch.

\begin{tabular}{|c|c|c|c|}
\hline Gender & $\%$ & Degree & $\%$ \\
\hline Female & 69.00 & primary school & 9.39 \\
\hline Male & 31.00 & secondary school & 29.91 \\
\hline Year of birth (age category) & $\%$ & higher non-university education & 26.64 \\
\hline $2000-2009$ & 6.33 & higher university education & 30.57 \\
\hline 1990-1999 & 35.15 & Missing & 3.49 \\
\hline 1980-1989 & 23.14 & Nationality & $\%$ \\
\hline 1970-1979 & 13.32 & Belgian & 75.11 \\
\hline 1960-1969 & 9.61 & French & 7.42 \\
\hline 1950-1959 & 6.99 & Italian & 3.28 \\
\hline 1940-1949 & 3.71 & Spanish & 2.84 \\
\hline missing & 1.75 & Dutch & 2.18 \\
\hline Income & $\%$ & Bulgarian & 0.87 \\
\hline less than $1000 €$ & 11.79 & Moroccan & 0.87 \\
\hline between 1000 and $1500 €$ & 11.14 & Canadian & 0.66 \\
\hline between 1500 and $3000 €$ & 28.38 & Chinese & 0.66 \\
\hline between 3000 and $5000 €$ & 8.30 & German & 0.66 \\
\hline more than $5000 €$ & 2.40 & US & 0.66 \\
\hline prefer not to answer & 37.99 & Missing & 1.09 \\
\hline & & Other $(<3$ respondents per nationality) & 3.71 \\
\hline
\end{tabular}

Table 2: Respondents' characteristics

\section{Results and discussion}

In this section we first present a descriptive analysis of chocolate consumption. Next we investigate the results of a conditional logit model that was used to estimate the probability that a particular 
product type was chosen by the respondents. This estimation allows us to calculate the respondents' WTP for different characteristics of the chocolate product. Lastly, we discuss the results of a latent class model to look for types and causes of observed consumer heterogeneity.

\subsection{Descriptive analysis of chocolate consumption}

As a control question, the respondents had to choose the six characteristics (out of eighteen) that they considered as important when buying chocolate (Figure 1). The color, taste and price were most frequently selected, followed by the type of chocolate product, the percentage of cocoa and the country of origin. Most respondents preferred milk chocolate (43\%) or dark chocolate (43\%), while only $9 \%$ preferred white chocolate ${ }^{6}$. From these results we already get a first insight into the relative importance of different chocolate characteristics since the characteristics related to taste clearly dominate ethical characteristics such as fairtrade or organic. This is in line with past studies looking at preferences for labeled food products (De Pelsmacker et al., 2005; Tagbata \& Sirieix, 2008; Rousseau, 2015).

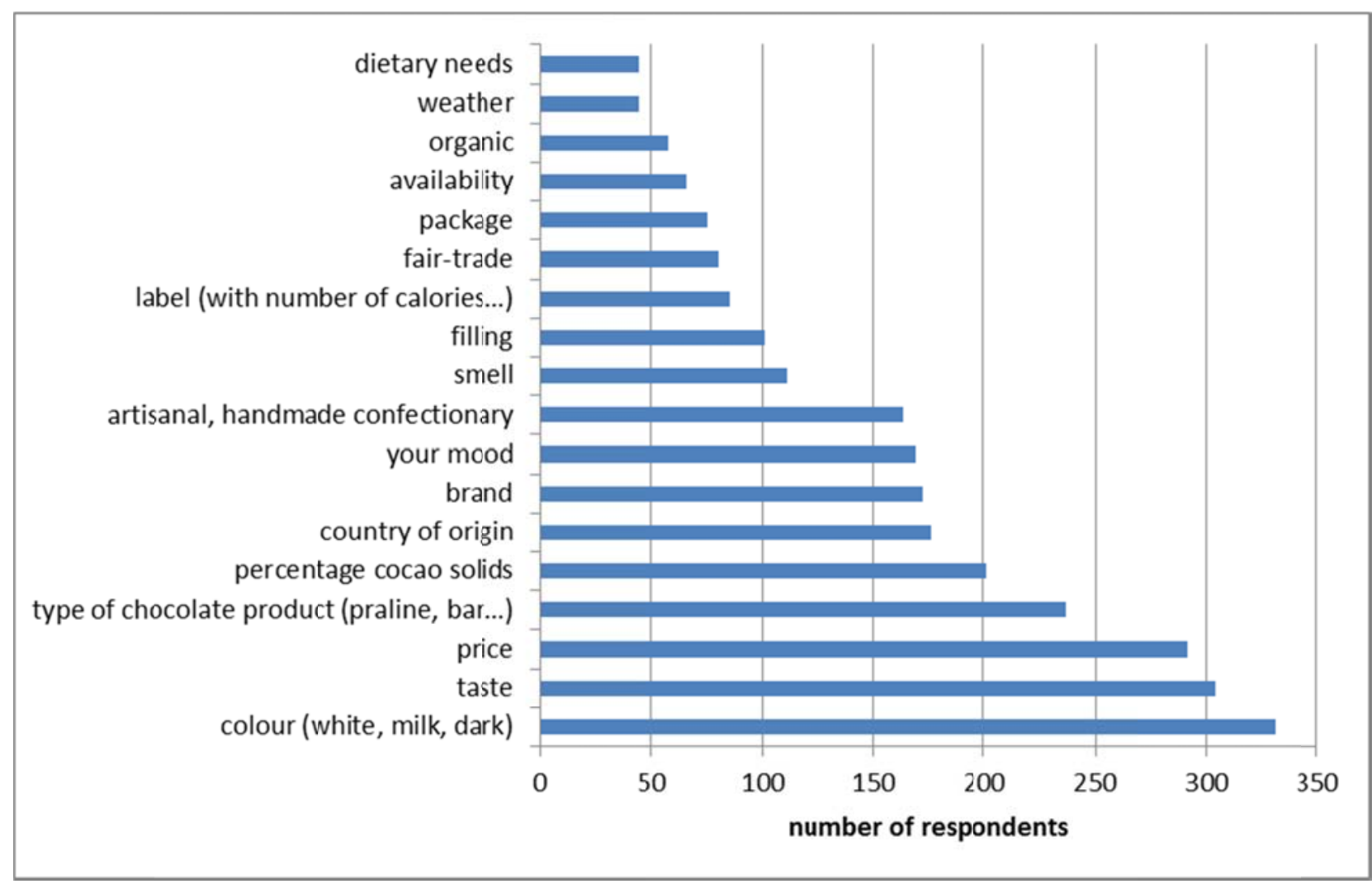

Figure 1: Factors determining chocolate consumption

\subsection{Logit model - main effects}

We now focus on the results from the stated choice experiment to get a clearer insight into the relative tradeoff between different chocolate characteristics. Based on the CL estimation (table 3),

${ }^{6}$ For $5 \%$ of the respondents this information was missing. 
we find that our respondents prefer chocolate tablets rather than boxed chocolate or chocolate bars, ceteris paribus. They strongly prefer Belgian chocolate and are indifferent between Chinese or American chocolate. The preference for Belgian chocolate can be due to a domestic reflex by the Belgian respondents, but it can also be due to the longstanding Belgian tradition of making high quality chocolate (Cidell \& Alberts, 2006). This illustrates the provenance effect where consumers associate certain geographies with the best products, such as Belgian or Swiss chocolates (Deshpandé, 2010). In addition, fairtrade chocolate is preferred over unlabeled chocolate, all else equal. This positive effect of fairtrade labelling for chocolate is in line with past research (Tagbata \& Sirieix, 2008; Rousseau, 2015). Moreover, an artisanal production process is preferred over an industrial one. The respondents show a marked preference for milk chocolate, followed by dark chocolate and finally white chocolate. Further, they dislike chocolate filled with liquor, but are indifferent between other types of filling and non-filled chocolate. Finally, as expected, they prefer cheaper chocolate over more expensive ones.

\begin{tabular}{|c|c|c|c|c|c|c|}
\hline & Coefficient & $\begin{array}{c}\text { Robust } \\
\text { standard } \\
\text { errors }\end{array}$ & P-value & $\begin{array}{c}\text { WTP } \\
\text { (euro per } \\
250 \mathrm{~g} \text { ) }\end{array}$ & $\begin{array}{c}95 \% \\
\text { lower } \\
\text { limit }\end{array}$ & $\begin{array}{c}95 \% \\
\text { upper } \\
\text { limit }\end{array}$ \\
\hline Tablet & $0.4593 * * *$ & 0.1211 & 0.000 & 19.74 & 4.31 & 35.16 \\
\hline Praline & $0.1133 *$ & 0.0663 & 0.087 & 4.87 & -1.28 & 11.02 \\
\hline Belgium & $1.0619 * * *$ & 0.0909 & 0.000 & 45.89 & 29.18 & 62.61 \\
\hline US & -0.0207 & 0.1206 & 0.864 & -0.89 & -11.06 & 9.28 \\
\hline Fairtradelabel & $0.2528 * * *$ & 0.0553 & 0.000 & 10.86 & 5.22 & 16.51 \\
\hline artisanal & $0.3149 * * *$ & 0.0657 & 0.000 & 13.53 & 7.02 & 20.04 \\
\hline Milk & $0.4158 * * *$ & 0.0931 & 0.000 & 17.87 & 7.31 & 28.43 \\
\hline Dark & $0.1993 * *$ & 0.0820 & 0.015 & 8.56 & 0.93 & 16.20 \\
\hline Filling & 0.0265 & 0.0659 & 0.687 & 1.14 & -4.33 & 6.61 \\
\hline Liquor & $-0.6359 * * *$ & 0.0921 & 0.000 & -27.33 & -40.08 & -14.58 \\
\hline Price & $-0.0233 * * *$ & 0.0043 & 0.000 & & & \\
\hline ASC1 & $-0.2706^{*}$ & 0.1421 & 0.057 & & & \\
\hline ASC2 & -0.1770 & 0.1475 & 0.230 & & & \\
\hline \multicolumn{7}{|c|}{$\begin{array}{l}\text { Number of obs. }=8136 \\
\text { Wald } \operatorname{chi}^{2}(13)=492.16 \\
\text { Prob }>\text { chi }^{2}=0.0000 \\
\text { Log pseudolikelihood }=-2594.5 \\
\text { Pseudo } \mathrm{R}^{2}=0.1292\end{array}$} \\
\hline
\end{tabular}

Table 3: CL estimation results $(* * * * * / *=$ statistical significant at $1 \% / 5 \% / 10 \%$ level) and WTP estimates based on CL results (results in italics $=$ not statistically significant at $5 \%$ level)

Based on these results, the marginal willingness to pay (WTP) for a change in one specific characteristic $k$ can be estimated as a ratio of the estimated coefficient for that characteristic $\left(\beta_{k}\right)$ and the estimated coefficient for the price variable $\left(\beta_{M}\right)$ :

$$
W T P=-\frac{\beta_{k}}{\beta_{M}}
$$

These results lead to the WTP estimates presented in table 3. We find that respondents are willing to pay a price premium of 10.86 euro per $250 \mathrm{~g}$ for fairtrade chocolate compared to an identical 
product without a fairtrade label ${ }^{7}$. As another example, respondents are willing to pay 13.53 euro extra per $250 \mathrm{~g}$ for chocolate that was artisanally produced compared to industrially produced chocolate.

Note that these WTP estimates represent a monetary estimate of the consumer surplus generated by consuming a particular type of chocolate and thus allows us to gain insight into the demand curve. Therefore, these estimates do not have to reflect the amounts actually paid by consumers and in general they will exceed shop prices. In this respect the WTP - as a measure of value ${ }^{8}$ - can exceed the actual amount paid for a product many times. Still, the WTP values in the current study are markedly higher than those in previous studies (Tagbata \& Sirieix, 2008; Rousseau, 2015). This may be due by the fact that our respondents were all visitors of the Salon $d u$ Chocolat and are thus likely to be chocolate lovers which could have an effect on their preferences for all chocolate characteristics.

Looking at the relative preferences for chocolate characteristics clearly reveals the dominance of provenance: the chocolate lovers in our sample have a clear preference for Belgian chocolate. The second most important characteristic is the absence of liquor in the filling, followed by the use of milk chocolate and an artisanal production process. All these elements, which can be associated with quality and taste, are found to be preferred more than the presence of a fairtrade label. These results show that consumers positively value both taste and ethical considerations, but that taste proxies clearly dominate the consumer choice for chocolate products.

Up to now we assume that the respondents have homogeneous preferences regarding the different attributes. However, in reality consumers tend to have heterogeneous preferences and it is often possible to distinguish between different groups of consumers. To accommodate heterogeneous preferences between consumer groups, we estimate a latent class model in the next section.

\subsection{Latent class model}

We now turn to the latent class estimation to have a closer look at the type and causes of observed consumer heterogeneity. We include three variables in the membership function to explain the latent classes: 1) the respondent's income class, 2) the respondent's preferred flavor of chocolate, and 3) the respondent's age. We tried to include several other variables in the estimation. However, the model performed best according to the AIC (Akaike Information Criterion) and the BIC (Bayesian Information Criterion) in the version reported in Table 4. The decision on the number of classes is guided by statistical decision criteria.

We can distinguish three classes of consumers in our sample: two groups of approximately $40 \%$ of respondents and a third group of some $19 \%$. Consumers in the first class have a strong preference

\footnotetext{
${ }^{7}$ The price range we used (going from 2 euro to 30 euro) reflects actual price ranges for these chocolate products. So when we compare an average price of 15 euro with the WTP of 10.8 euro for $250 \mathrm{~g}$ fairtrade chocolate, this would imply a price premium of $72 \%$.

${ }^{8}$ A simple gift can have a price of 500 euro in the shop, but the value of that gift can greatly exceed the shop price for its owner, because of certain of its attributes, such as the fact that the item was a gift given by someone you love.
} 
for Belgian chocolate and they clearly prefer tablets over pralines and snack bars. They dislike chocolate with a liquor filling. In addition, these respondents have clear preferences regarding taste. They like milk chocolate most, followed by dark chocolate and finally white chocolate. These consumers prefer chocolate that is produced in an artisanal way and they have a preference for labeled fairtrade chocolate. Since these respondents do not seem to be sensitive to the price mentioned on the choice cards, we could not calculate the specific WTP for fairtrade chocolate for this group. However, based on the relative size of the estimated coefficient, we clearly see that this group positively values taste and fairtrade characteristics of chocolates, but that taste has a much greater impact than the presence of a fairtrade label.

Consumers in the second class are indifferent with respect to the type of chocolate. They still reveal a strong provenance effect (Deshpandé, 2010) since they prefer Belgian chocolate over American chocolate and they like Chinese chocolate least of all. These consumers also like artisanal produced chocolate and chocolate with a fairtrade label, but they dislike chocolate with a liquor filling. These respondents are willing to pay a premium of 5.75 euro per $250 \mathrm{~g}$ for fairtrade chocolate. Further, they prefer dark chocolate, then milk chocolate, and they like white chocolate least. Note that this group of consumers frequently indicated that they did not like the two chocolate products presented in a particular choice card (i.e. the ASCs are negative and significant). This might indicate that this group of respondents only liked very specific types of chocolate and if these were not included in a particular choice set, they would select neither of the two available varieties. Thus, this group of consumers seems to have strong preferences for chocolate, especially regarding its taste characteristics. Ethical consideration such as the fairtrade label are valued to a much lesser extent. The dominance of taste is more pronounced in this consumer segment than in the first class.

\begin{tabular}{|c|c|c|c|}
\hline & Class 1 & Class 2 & Class 3 \\
\hline tablet & $0.941 * *$ & 0.061 & -0.008 \\
\hline praline & 0.148 & 0.244 & -0.362 \\
\hline belgium & $1.400 * * *$ & $1.973 * * *$ & -0.137 \\
\hline us & $0.528 *$ & $0.505^{*}$ & $-0.984 * *$ \\
\hline fairtradelabel & $0.535 * * *$ & $0.293 *$ & -0.127 \\
\hline artisanal & $0.370 * * *$ & $0.518 * * *$ & -0.067 \\
\hline milk & $0.933 * *$ & $0.725 * * *$ & 0.423 \\
\hline dark & $0.681 * * *$ & $1.107 * * *$ & $-1.596 * * *$ \\
\hline filling & 0.009 & 0.088 & 0.065 \\
\hline liquor & $-0.596^{*}$ & $-0.857 * * *$ & $-1.544 * * *$ \\
\hline price & 0.003 & $-0.051 * * *$ & $-0.062 * * *$ \\
\hline ASC1 & 0.493 & $-2.301 * * *$ & $2.269 * * *$ \\
\hline ASC2 & 0.564 & $-2.253 * * *$ & $2.645^{* * *}$ \\
\hline Class share & 0.433 & 0.382 & 0.186 \\
\hline \multicolumn{4}{|c|}{ Membership function } \\
\hline Income & 0.146 & $0.184 *$ & \\
\hline Flavor & $1.392 * * *$ & $1.733 * * *$ & \\
\hline Age & $0.042 * *$ & $0.046^{* * *}$ & \\
\hline cons & $-3.839 * * *$ & $-5.115^{* * *}$ & \\
\hline
\end{tabular}

$*=$ significant at $10 \%$ level; $* *=$ significant at $5 \%$ level; $* * *=$ significant at $1 \%$ level

Table 4: Latent class estimation 
Consumers in the smaller third class are indifferent with respect to the type of chocolate, the presence of a fairtrade label, and the type of production process. They have a strong dislike of American chocolate compared to Chinese or Belgian chocolate and they do not like liquor-flavored filling. These consumers are indifferent between white and milk chocolate, but they decidedly do not like dark chocolate. These respondents also are the most price sensitive of our sample. Further, since the ASCs are positive and significant, these respondents seem to prefer any type of chocolate over no chocolate at all. These consumers seem to have weak preferences for most chocolate characteristics. While they positively value some taste characteristics, they seem to be indifferent regarding ethical characteristics.

Overall, we were able to distinguish three consumer segments that balance taste and ethical considerations differently: a first group that positively valued taste and to a lesser extent fairtrade; a second group that positively valued taste and to a much lesser extent fairtrade, and a third group that positively valued taste but did not value fairtrade. To describe the type of respondents in each of these three classes, we present the means for several consumer characteristics ordered by the three different classes in table 5. We use paired t-tests to test whether the differences between these means are statistically significant.

\begin{tabular}{|l|c|c|c|c|c|c|}
\hline & Class 1 & Class 2 & Class 3 & $\begin{array}{c}\text { Class1 vs } \\
\text { Class2 }\end{array}$ & $\begin{array}{c}\text { Class1 vs } \\
\text { Class3 }\end{array}$ & $\begin{array}{c}\text { Class2 vs } \\
\text { Class3 }\end{array}$ \\
\hline Belgian (\%) & 74.1 & 74.0 & 76.5 & & $* *$ & $* *$ \\
\hline French (\%) & 8.4 & 5.2 & 9.8 & $* * *$ & $*$ & $* * *$ \\
\hline Europe (other) (\%) & 10.5 & 12.7 & 9.8 & $* * *$ & & $* * *$ \\
\hline Rest of the world (\%) & 5.4 & 5.2 & 2.0 & & $* * *$ & $* * *$ \\
\hline Female (\%) & 70.7 & 61.3 & 80.4 & $* * *$ & $* * *$ & $* * *$ \\
\hline Age (in years) & 26.70 & 38.36 & 19.5 & $* * *$ & $* * *$ & $* * *$ \\
\hline Student (\%) & 41.0 & 26.0 & 70.6 & $* * *$ & $* * *$ & $* * *$ \\
\hline University degree (\%) & 29.7 & 35.8 & 13.7 & $* * *$ & $* * *$ & $* * *$ \\
\hline Single (\%) & 48.5 & 31.2 & 64.7 & $* * *$ & $* * *$ & $* * *$ \\
\hline Eat frequent chocolate (\%) & 2.9 & 0.6 & 11.8 & $* * *$ & $* * *$ & $* * *$ \\
\hline Eat seldom chocolate (\%) & 69.5 & 69.9 & 56.9 & & $* * *$ & $* * *$ \\
\hline Eat small portion (\%) & 30.1 & 52.0 & 21.6 & $* * *$ & $* * *$ & $* * *$ \\
\hline Like white chocolate (\%) & 2.1 & 0.0 & 72.5 & $* * *$ & $* * *$ & $* * *$ \\
\hline Like milk chocolate (\%) & 74.9 & 1.7 & 27.5 & $* * *$ & $* * *$ & $* * *$ \\
\hline Like dark chocolate (\%) & 23.0 & 82.7 & 0.0 & $* * *$ & $* * *$ & $* * *$ \\
\hline High income (\%) & 0.4 & 5.8 & 0.0 & $* * *$ & $* *$ & $* * *$ \\
\hline
\end{tabular}

*/**/***: difference between means is statistically significant at $10 \% / 5 \% / 1 \%$ level ( $t$-test)

Table 5: Variable means grouped by classes

Looking at the type of consumers in each of the consumer segments, we see that the group that does not value fairtrade (class 3 ) consists mainly of younger females $(70 \%$ is still at school or university; $80 \%$ is female) who frequently eat chocolate and have a preference for sweeter - white or milk chocolate. The group that positively values fairtrade but only to a minor extent (class 2) has the highest share of male respondents (39\%), has the highest average age (38 years), and has the highest share of high income households (i.e. monthly net income of more than 5000 euro). This 
class includes the lowest share of respondents who frequently eat chocolate (i.e. at least once per day) and these respondents clearly prefer dark chocolate. The final group that values fairtrade relatively the most is average regarding most characteristics, except that these respondents have a marked preference for milk chocolate.

\section{Conclusion}

We investigated chocolate lovers interest in fairtrade by estimating their willingness to pay for fairtrade chocolate products. We focused on visitors of the Salon du Chocolat in Brussels, Belgium in February 2014. A majority of respondents was female and quite young (some $60 \%$ were between 15 and 34 years old). Most respondents (75\%) had the Belgian nationality.

The results of the choice experiments are in line with previous studies and show that our respondents prefer chocolate tablets rather than boxed chocolate or chocolate bars, ceteris paribus. Moreover, they strongly prefer Belgian chocolate and are indifferent between Chinese or American chocolate. The preference for Belgian chocolate may be due to a provenance effect or to a domestic effect. In addition, fairtrade chocolate is preferred over unlabeled chocolate, all else equal. On average, respondents were willing to pay 11 euro more for $250 \mathrm{~g}$ fairtrade chocolate compared to conventional chocolate. This is a significantly higher value than was obtained in previous studies which may be due to the fact that we specifically sampled chocolate lovers. Furthermore, an artisanal production process is preferred over an industrial one. The respondents show a marked preference for milk chocolate, followed by dark chocolate and finally white chocolate. Further, they dislike chocolate filled with liquor, but are indifferent between other types of filling and non-filled chocolate. Finally, they prefer cheaper chocolate over more expensive products.

Thus, besides taste and quality characteristics, the chocolate lovers seem to take ethical considerations into account when selecting chocolate. However, taste clearly dominates their choices. Looking at our results in more detail, we can distinguish three classes of consumers in our sample. Two of those classes had a positive preference for fairtrade chocolate, while the third class was indifferent to this characteristic. The group that did not seem to value fairtrade consisted mainly of young females with an average age of 19 and a preference for white chocolate. On the other hand, the group that preferred fairtrade most reflected the average socio-demographic characteristics in our sample, but preferred to eat milk chocolate.

The dominance of taste over fairtrade characteristics shows that chocolate producers should continue to pay attention to the taste of their products. Producers will not be able to convince large shares of consumers to pay a higher price for fairtrade chocolate simply because it has a fairtrade label. Consumers preferences are guided in the first place by the taste (and origin) of the products and only to a much lesser extent by ethical considerations. Moreover, the significantly different average age of the respondents in the three market segments can imply that producers should focus their marketing efforts regarding fairtrade chocolate products on mature consumers. Finally, we also observed that the consumer segment that valued fairtrade most had a preference for chocolate 
tables and milk chocolate. This result can encourage producers to carefully select the chocolate products which they would want to certify. However, some follow-up studies are needed to investigate the robustness of these results.

Finally, it is also interesting to see how our results carry over to other samples of for example consumers that occasionally consume chocolate. Moreover, some further research into the characteristics that determine the different consumers fragments seems to be worthwhile. 


\section{References}

Amaya-Amaya, M., Gerard, K. \& Ryan, M. (2008). Discrete choice experiments in a nutshell. In: M. Ryan, K. Gerard and M. Amaya-Amaya (eds.), Using Discrete Choice Experiments to Value Health and Health Care, 13-46. Springer.

Andorfer, V.A. \& Liebe, U. (2012). Research on Fair Trade Consumption-A Review. Journal of Business Ethics, 106, 415-435.

Annunziata, A., Ianuario, S. \& Pascale, P. (2011). Consumers' attitudes towards labelling of ethical products: The case of organic and fair trade products. Journal of Food Products Marketing, 17(5), 518-535.

Annunziata, A. \& Scarpato, D. (2014). Factors affecting consumer attitudes towards food products with sustainable attributes. Agricultural Economics, 60, 8, 353-363.

Barrientos, S. (2015, forthcoming), Beyond Fair Trade: Why are Mainstream Chocolate Companies Pursuing Social and Economic Sustainability in Cocoa Sourcing?, in Squicciarini, M. and Swinnen, J. (eds.) The Economics and Politics of Chocolate, Oxford university Press, Oxford.

Basu, A.K. \& Hicks, R.L. (2008). Label performance and the willingness to pay for fair trade coffee: a cross-national perspective. International Journal of Consumer Studies, 32, 470-478

Boxall, P.C. \& Adamowicz, W.L. (2002). Understanding heterogeneous preferences in random utility models: A latent class approach. Environmental and Resource Economics, 23, 421-446

CAOBISCO (2013). Statistical bulletin. Retrieved from:

https://www.mah.se/PageFiles/55093/caobisco-statistical\%20bulletin\%202013.pdf

Carrigan, M. \& Attalla, A. (2001). The myth of the ethical consumer: Do ethics matter in purchase behavior. Journal of Consumer Marketing, 18(7), 560-577

Caswell, J.A. (1998). Valuing the benefits and costs of improved food safety and nutrition. Australian Journal of Agricultural and Resource Economics, 42(4), 409-424

Christie, M., Warren, J., Hanley, N., Murphy, K., Wright, R., Hyde, T. \& Lyons, N. (2004). Developing measures for valuing changes in biodiversity: Final report. Report to DEFRA London.

Cidell, J.L. \& Alberts, H.C. (2006). Chocolate consumption, manufacturing and Quality in Western Europe and the United States. Geography, 91(3), 218-226.

Clough, Y., Faust, H. \& Tscharntke, T. (2009). Cacao boom and bust: sustainability of agroforests and opportunities for biodiversity conservation. Conservation Letters, 2, 197-205.

De Pelsmacker, P., Driesen, L. \& Rayp, G. (2005). Do consumers care about ethics? Willingness to pay for fair-trade coffee. The Journal of Consumer Affairs, 39(2), 363-385.

Deshpandé, R. (2010). Why you aren’t buying Venezuelan chocolate. Harvard Business Review, December, 25-27 
Douce, S. \& Jeantet, F. (2014) Salon du Chocolat, Success Story. Retrieved from : http://www.salon-du-chocolat.com/evenement.aspx?event_id=97

Dragusanu, R., Giovannucci, D. \& Nunn, N. (2014). The Economics of Fair Trade. Journal of Economic Perspectives, 28(3), 217-236.

Fairtrade Foundation (2011). Commodity Briefing: Fairtrade and Cocoa. Retrieved from: http://www.fairtrade.net/fileadmin/user_upload/content/2009/resources/2011_Fairtrade_and_cocoa briefing.pdf

Fairtrade Foundation (2012). Tracking fairtrade cocoa. Retrieved from: http://www.fairtrade.org.uk/en/media-centre/news/archive/tracking-fairtrade-cocoa

Fairtrade Foundation (2014). Farmer-owned chocolate company beats big brands in poll of nation's favourite faitrade product, 16 October 2014. Retrieved from: http://www.fairtrade.org.uk/en/mediacentre/news/october-2014/farmer-owned-chocolate-brand-named-nations-favourite-fairtradeproduct

Fairtrade International (2012). Fairtrade by the numbers: key data for 2009-11. Retrieved on 4 September 2014 from www.fairtrade.net/fileadmin/user_upload/content/2009/resources/201202_Fairtrade_ByTheNumbers_2009-11.pdf

Fairtrade International (2014). Year report 2013-2014: Strong producers, strong future. Retrieved from: http://www.fairtrade.net/annual-reports.html

Fold, N. (2002). Lead firms and competition in "bi-polar" commodity chains: Grinders and branders in the global cocoa-chocolate industry. Journal of Agrarian Change, 2(2), 228-247.

Fountain, A.C. \& Hütz-Adams, F. (2007). Sweetness Follows: A rough guide towards a sustainable cocoa sector. Retrieved November 11, 2014: http://www.cocoabarometer.org/Download files/

Fountain, A.C. \& Hütz-Adams, F. (2010). Cocoa Barometer 2010. Retrieved November 11, 2014 : http://www.cocoabarometer.org/Download_files/

Fountain, A.C. \& Hütz-Adams, F. (2012). Cocoa Barometer 2012. Retrieved November 11, 2014 : http://www.cocoabarometer.org/Download files/

Garcia-Yi, J. (2015). Willingness to pay for organic and fairtrade certified yellow chili peppers. British Food Journal, 117(2), 929-942.

Haight, C. (2011). The Problem with Fair Trade Coffee. Stanford Social Innovation Review. Retrieved November 3, 2015: http://ssir.org/articles/entry/the problem with fair_trade_coffee

Hanley, N., Mourato, S. \& Wright, R.E. (2001). Choice modeling approaches: A superior alternative for environmental valuation? Journal of Economic Surveys, 15(3), 435-462

Hensher, D., Louviere, J. \& Swait, J. (1999). Combining sources of preference data. Journal of Econometrics, 89, 197-222 
ICCO. (2007a). Cocoa Resources in consuming countries. (Report NO. MC/10/6). London.

Retrieved from:

http://s3.amazonaws.com/zanran_storage/www.icco.org/ContentPages/16291656.pdf

ICCO (2007b). Sustainable cocoa economy: A comprehensive and participatory approach. Report No. CB/14/2. London: International Cocoa organization.

ICCO (2009). Towards a sustainable cocoa economy: Overview of farming systems and challenges facing cocoa farmers worldwide. Roundtable for a Sustainable Cocoa Economy 2/6. London: International Cocoa Organization.

ICCO (2012). The World Cocoa Economy: Past and Present (EX/146/7). Retrieved from: http://www.icco.org/about-us/international-cocoa-agreements/cat view/30-related-documents/45statistics-other-statistics.html

ICCO (2014). The Chocolate Industry: Who are the main manufacturers of chocolate in the world?. Retrieved from: http://www.icco.org/about-cocoa/chocolate-industry.html

IDH (2014). Cocoa: Strong business case creates unprecedented drive for mainstream market transformation. Retrieved August 20, 2014: http://www.idhsustainabletrade.com/cocoa

Januszewska, R., Viaene, J. \& Verbeke, W. (2000). Market segmentation for chocolate in Belgium and Poland. Journal of Euromarketing, 9(3), 1-25

Januszewska, R. \& Viaene, J. (2001). Sensory segments in preference for plain chocolate across Belgium and Poland. Food Quality and Preference, 12, 97-107

Jawtusch, J.; Oehen, B. \& Niggli, U. (2012). Environmental, Social, and Economic Impacts of Sustainability Certification in the Agricultural Sector - The Current State of Empirical Research. in: FIBL and IFOAM, The World of Organic Agriculture - statistics \& Emerging Trends 2011, IFOAM, Bonn.

KPMG (2012a). Cocoa Certification: Study on the costs, advantages and disadvantages of cocoa certification. Commissioned by The International Cocoa Organization (ICCO).

KPMG (2012b). The chocolate of tomorrow: State of the market (Publication No. 120788).

Retrieved from http://www.kpmg.com/be/en/issuesandinsights/articlespublications/pages/chocolateof-tomorrow.aspx

Le Mare, A. (2008).The impact of fair trade on social and economic development: a review of the literature. Geography compass. 2(6), 1922-1942.

List, J.A. \& Gallet, C.A. (2001). What experimental protocol influence disparities between actual and hypothetical stated values? Environmental and Resource Economics, 20, 241-254

List, J.A. \& Shogren, J.F. (1999). Price information and bidding behavior in repeated second - price auctions. American Journal of Agricultural Economics, 81, 942-949 
Loureiro, M.L. \& Lotade, J. (2005). Do fair trade and eco-labels in coffee wake up the consumer conscience? Ecological Economics, 53, 129-138.

Louviere, J.J. \& Hensher, D.A. (1982). On the design and analysis of simulated choice or allocation experiments in travel choice modelling. Transportation Research Record, 890, 11-17.

Louviere, J.J. \& Woodworth, G. (1983). Design and analysis of stimulated choice experiments or allocation experiments: An approach based on aggregate data. Journal of Marketing Research, 20, 350-367.

Lusk, J.L., \& Shogren, J.F. (2007). Experimental auctions: Methods and applications in economic and marketing research. Cambridge University Press.

Lybeck, A., Holmlund-Rytkönen, M. \& Sääksjärvi, M. (2006). Store brands vs. manufacturer brands: Consumer perceptions and buying of chocolate bars in Finland. The International Review of Retail, Distribution and Consumer Research, 16(4), 471-492

Mariel, P., De Ayala, A., Hoyos, D. \& Abdullah, S. (2011). Selecting random parameters in discrete choice experiment for environmental valuation: a simulation experiment. International Choice Modelling Conference 2011, Oulton Hall, UK.

McFadden, D. (1986). The choice theory approach to market research. Marketing Science, 5, 275297

Myers, N., Mittermeier, R.A., Mittermeier, C.G., da Fonseca, G.A.B., \& Kent, J. (2000) Biodiversity hotspots for conservation priorities. Nature, 403, 853-858.

Nelson, V. \& Pound, B. (2009) The last ten years: a comprehensive review of the literature on the impact of fairtrade. Commissioned by the Faitrade Foundation. Retrieved from www. fairtrade.net on November, $2^{\text {nd }}, 2015$.

Nieburg, O. (2014). Fully certified cocoa "a prerequisite for doing business in chocolate", Cloetta tells SMEs. Confectionery News. Retrieved August, 26: http://www.confectionerynews.com

Norwood, F. B., \& Lusk, J. L. (2011). Social desirability bias in real, hypothetical, and inferred valuation experiments. American Journal of Agricultural Economics, 93(2), 528-534.

Oxfam (2013). Behind the brands: Food justice and the "Big 10" food and beverage companies. Retrieved August 26, 2014: www.oxfam.org.

Pay, E. (September 2009), The market for organic and fairtrade cocoa, Study prepared in the framework of FAO project GCP/RAF/404/GER. Retrieved from: http://www.fao.org/fileadmin/templates/organicexports/docs/Market_Organic_FT_Cocoa.pdf

Poelman, A., Mojet, J., Lyon, D. \& Sefah-Dedeh, S. (2008). The influence of information about organic production and fair trade on preferences for and perception of pineapple. Food Quality and Preference, 19, 114-121 
Poelmans, E. \& Swinnen, J. (2016, forthcoming). A brief economic history of chocolate, in Squicciarini, M. and Swinnen, J., The Economics and Politics of Chocolate, Oxford University Press, Oxford.

Redruello, F. (2012). 10 Key Projections for Chocolate Confectionery in 2013 and Beyond. Retrieved from http://www.portal.euromonitor.com

Rice, R.A. \& R. Greenberg (2000). Cacao cultivation and the conservation of biological diversity. AMBIO: A Journal of the Human Environment, 29(3), 167-173.

Rousseau, S. (2015). The role of organic and fair trade labels when choosing chocolate. Food Quality and Preference, 44, 92-100

Ruben, R. and Ford, R. (2012). The Impact of Fair Trade Certification for Coffee Farmers in Peru. World Development, 40(3), 570-582.

Smith, A.F. (ed.), (2004), The Oxford Encyclopedia of Food and Drink in America, volume 1, Oxford University Press, Oxford.

SSI (2014). The State of Sustainability Initiatives Review: Sustainability and transparency. Retrieved August 18, 2014: www.cocoaconnect.org.

Tagbata, D. \& L. Sirieix (2008). Measuring consumers' willingness to pay for organic and Fair Trade products. International Journal of Consumer Studies, 32, 479-490.

Tallontire, A., Rentsendorj, E. \& Blowfield, M. (2001). Ethical consumers and ethical trade: a review of current literature. Policy Series, 12, 1-35.

Torres-Moreno, M., Tarrega, A., Torrescasana, E. \& Blanch, C. (2012). Influence of label information on dark chocolate acceptability. Appetite, 58, 665-671

Trade for Development Center (2014). Gedrag, attitudes en opinies van personen die in België wonen ten aanzien van producten uit eerlijke handel. Retrieved from http://befair.be/sites/default/files/all-

files/brochure/Resultaten\%20Opiniepeiling\%20Eerlijke\%20Handel\%202014.pdf

Train, K.E. (2003). Discrete Choice Methods with Simulations (1 ed.). Cambridge: Cambridge University Press

Vermeir, I. \& Verbeke, W. (2006). Sustainable food consumption: Exploring the consumer "attitude - behavioral intention" gap. Journal of Agricultural and Environmental Ethics, 19(2), 169-194

Vlaeminck, P., Vandoren, J. \&Vranken, L. (2015, forthcoming). Consumers' willingness to pay for Fair Trade chocolate, in Squicciarini, M. and Swinnen, J., The Economics and Politics of Chocolate, Oxford University Press, Oxford.

Vossler, C.A., Doyon, M. \& Rondeau, D. (2012). Truth in consequentiality: Theory and field evidence on discrete choice experiments. American Economic Journal: Microeconomics, 4(4), 145171 
Yiridoe, E.K., Bonti-Ankomah, S. \& Martin, R.C. (2005). Comparison of consumer perceptions and preference toward organic versus conventionally produced foods: A review and update of the literature. Renewable Agriculture and Food Systems, 20(4), 193-205

Zander, K. \& Hamm, U. (2010). Consumer preferences for additional ethical attributes of organic food. Food Quality and Preference, 21, 495-503 